\title{
The Determinants of Employee Ownership Plan Implementation in EU Countries - the Quest for Economic Democracy: a First Look at the Evidence
}

\author{
Ricardo B. Machado
}

\author{
Porto Polytechnic, School of Management and Industrial Studies (ESEIG), Vila do Conde, Portugal \\ rmachado@eseig.ipp.pt
}

\begin{abstract}
Background and purpose: Kelso's quest to identify the economic counterpart of political democracy and, as a corollary, his concern about the nature of the economic system's organisation needed to support the institutions of a politically free society, contributed two important terms: economic power and democracy. Following Kelso's reasoning, my research study aims to understand the determinants of the implementation of economic democracy, measured by the incidence of employee share ownership plans, within European Union countries.

Methodology: Setting out with the theory of one of the founding fathers of employee stock ownership plans, I perform a cross-country analysis spanning five years (2008-2012) to explain the incidence level of employee ownership by independent variables operationalizing the political, legal, socio-educational and economic structures of twenty European Union countries. Using secondary data from the European Federation of Employee Share Ownership, I explain the determinants' pertinence, while accounting for severe data limitations.

Results: I report a strong correlation between employee ownership incidence and the index of economic freedom. However, the labour market's freedom, the trustworthiness of and confidence in financial markets and the quality of secondary and tertiary education do not deliver clear-cut results.

Conclusion: Further research should comprehensively scrutinise country-specific factors regarding corporate governance issues and cross-cultural controls. Employee ownership researchers should consider this field of research to understand why countries that are so-called employee ownership champions are experiencing widening income inequality.
\end{abstract}

Keywords: employee ownership, economic democracy, free markets, economic freedom, equity markets

\section{Introduction}

Considering the famous assertion by Winston Churchill that democracy is the worst form of government system, with the exception of all other forms, it can be said that democracy gives people the fundamental right to control their own destiny through representatives. Political democracy provides us always with alternative options to the status quo. From the neoliberal radical standpoint to the Deweyan perceived shallowness of the concept in everyday economic life, through democracy, there can be a way for nations, and a fortiori, citizens, to become more independent from financial markets' constricting forces resulting in income accumulation in the hands of a small percentage of owners. However, where is the limit to the morbid nature of excess income? Kelso and Kelso (1991) put it straightforwardly, saying that morbid capital is a capital holding which produces income above the amount its proprietor needs to cover his/her living standards - in other words, it is capital above individual or household consumption needs.

I propose adding another requirement to recognise the above-advocated non-morbid capital boundary: ... and put 
capital to work in productive investments. This amendment is in line with one of Terrell's (2005) harsh criticisms of Kelso's and binary economists' theories ${ }^{1}$; to be precise, binary economists fail to identify 'the importance of labor and innovation in the development of capital', going far beyond producing only consumer goods (Terrell, 2005, p. 34).

Nevertheless, the assertion fully depicts the limitations on ownership rights in common law, subsumed in the indisputable principles of the owner. When exerting property rights, (1) the owner should neither injure the property of his/her neighbour nor (2) the public interest. Following Kelso and Kelso (1991), this is precisely what morbid capital does because:

Without benefiting its owners, it beggars others by depriving them the adequate economic opportunity [violation of common law limitation on private property] (...) [and] is contrary to the public interest because it results in strife and suffering and is economically undemocratic [violation of the public interest and welfare common law limitation]. (p. 168)

The urge to diminish income inequality throughout the world is the basis for the seminal employee ownership theory put forward by Louis O. Kelso and Mortimer Adler in the then-revolutionary book The Capitalist Manifesto (Kelso and Adler, 1958). In 1958, Kelso and Adler posed two fundamental questions. The first related to the quest for the economic counterpart of political democracy, while the second, as a corollary, was concerned with the nature of the economic organisation needed to support the institutions of a politically free society. They emphatically gave the answer 'economic democracy' - a system that grants people's right to participate in 'the power to produce goods and services and to receive the income so earned'.

Six decades later, Blasi, Freeman, and Kruse (2014) - three of world's most preeminent academic experts on employee ownership - postulated with firmness and conviction that major diffusion of employee ownership is the most effective device for coping with the world's deepening wealth distribution inequality. Thus, they coined the solution of broad-based capitalism, stating that:

A Google search for 'economic inequality' finds millions of entries from politicians, policy analysis, business and labor leaders, and citizens with widely divergent perspectives and ideological persuasions. In a world in which the distribution of national income has shifted from labor to capital, in which ownership of financial assets and access to income form capital is highly concentrated, and in which a small number of high earners have pulled away from the rest of the society, a person does not have to be paranoid to be alarmed about the dangers that continual widening of income and wealth distribution poses for the wellbeing of the economy and society (Blasi et al., 2014, p.x).

The acknowledgement of the widening income inequality fifty-six years after the emergence of the capitalist (revolutionary) manifesto represents a harsh reality. Still, as Freeman (2014) posited:

Unless workers earn income from capital as well as from labor, the trend toward a more unequal income distribution is likely to continue, and the world will increasingly turn into a new form of economic feudalism. We have to widen the ownership of business capital if we hope to prevent such a polarization of our economies (pp. 7-8).

The basic idea is that the actual tendency which favours excessive capital accumulation will soon hinder economic growth, since it creates a diminishing purchasing power amongst the majority of citizens. Thus, the capital latency instigated by economic inequality will counteract an economy's wealth creation, resulting in economic stagnation. Conversely, as noted by Ashford (2011), none of the well-known and acknowledged theorists of economic growth recognise the potentialities of capital acquisition distribution to citizens in relation to the sustainable development of economies.

Yet, what about 'economic democracy'? Is the rationale behind that concept clear? If so, is it measurable? In a straightforward explanation, Kelso and Kelso (1991) explain it by means of the employees' right to share a firm's income, not only through their workforce participation, but also as owner, entitled to a stake in wealth accumulation.

Since the 1950s, a growing body of evidence about the benefits and/or the widespread usage of employee ownership schemes have emerged, predominantly in the form of employee stock ownership plans. This primarily occurred in the United States, well ahead of Europe. In the latter region, it was boosted by European Union institutions and bodies in mid-1970s and experienced a definite take-off with the publication of the first PEPPER ${ }^{2}$ report (Uvalic, 1991).

\section{Methodology}

I consider the broader motives for the implementation of employee share ownership schemes reported in five major categories, as follows: ${ }^{3}$ (1) firm performance studies (using economic and financial performance measures of profitability and productivity within a varied set of methodological frameworks); (2) studies focused on workers'

${ }^{1}$ For a comprehensive literature review of the theories of Kelso and Binary Economics, see, for instance, Ashford (1994), Kurland (2001) or Zundel (2000).

${ }^{2}$ Acronym for Promotion of Employee Participation in Profits and Enterprise Results.

${ }^{3}$ For more details about the studies included in each category and major European Union initiatives towards employee financial participation plans, see Machado (2011). 
(individual) attitudinal effects (motivation, commitment, or employee job satisfaction); (3) deriving from (2), studies focussed on researching the organisational impact of workers' psychological ownership (the feeling or perception of ownership) rather than formal ownership, defined as

That state [of mind] in which individuals feel as though the target of ownership (material or immaterial in nature) or a piece of it is 'theirs' (...). The core of psychological ownership is the feeling of possessiveness and of being psychologically tied to an object (Pierce et al., 2001, p. 299);

(4) employee ownership plans as a compensation vehicle used as an anti-takeover defence; and (5) research studies which examine the impact of employee ownership on trade unions (density and influence level) and collective bargaining. ${ }^{4}$

Given the positive effects demonstrated by the studies whose categories are listed above, studies are missed that investigate the factors that determine the implementation of employee ownership at the level of societies. It is time to break through to another kind of employee ownership research in order to open up a view on foundational causes that might also be able to account for the discrepancies in employee ownership plan dissemination throughout the European Union. Actually, some European practitioners, regulators and promoters of employee ownership keep asking about the nature and extent of factors that might impede the further implementation of broad based employee ownership schemes in the EU, particularly since the big push created by the publication of the PEPPER II report (European Commission, 1996), followed by the 2002 Commission's recommendation (European Commission, 2002). ${ }^{5}$ Considering this, researchers should pose the following question: Which country-specific factors determine the employee ownership incidence level throughout the EU?

\subsection{Background}

As Poutsma (2001) points out, for a better understanding of uneven and widespread financial participation schemes, researchers must concentrate their efforts on the implementation process and drawbacks according to countries' political, economic, legal and social environments, which influence the approach of doing business. Far from assuming a cultural deterministic theory to draw conclusions related to the stated differences, the growing group of em- ployee ownership promoters must understand how the potential to introduce broad-based share ownership plans can boost citizens' economic participation as owners. For instance, Pendleton, Poutsma, van Ommeren, and Brewster (2001, 2003) also focus on specific factors in EU member states that explain plans' implementation determinants, concluding that 'nationality' is the key factor explaining the incidence of broad-based employee ownership plans.

McCartney (2004) highlights the national-level policies and country-specific factors as the driving factors for the development of employee ownership plans. To be exact, considering countries' cultural differences, he emphasises the need to change tax policies to include tax benefits and allowances for both parties, as with labour laws, financial markets supervision rules and corporate governance standards. He stresses the necessity of training practices engaged in explaining the plans' complexities to workers. Economic and financial (or business) literacy appears to play a major role in employee ownership plan diffusion at both the national and company levels, which has been recognised by several studies that did not focus on this issue exclusively, but instead considered it as a corollary of workers' education level or literacy as a whole (e.g. Black and Lynch, 2001; Ichniowski et al., 1997; Pendleton et al., 2001, 2003). However, empirical evidence on this subject is still lacking (Kaarsemaker et al., 2010).

Beyond community policies and recommendations providing the major guidelines for plan implementation at a national level, Poutsma and Nijs (2003) stress that there are fundamental country-specific factors which are shaped by their own institutional environment - this is the nation's breeding ground. Here, national institutions and citizens play a major role in setting up distinctive social models - specifically, sociocultural patterns which affect how companies are run and organised - that are critical for employee ownership plan diffusion and determine their configuration. Therefore, the differences in the prevalence of those plans in different states should be highlighted in relation to four fundamental dimensions, as follows: (a) labour relations, (b) capital markets, (c) governance and (d) corporate governance.

In order to cope with country-specific factors and to test the incidence level in European Union members, I consider economic policy-related issues, regulation of labour markets, the development of capital markets and financial literacy.

${ }^{4}$ For another comprehensive literature review with a somewhat different classification, see Hashi and Hashani (2013).

${ }^{5}$ As an example, Norbert Kuhn (2015) - head of Corporate Finance at Deutsches Aktieninstitut, an association of companies, investors, banks, stock exchanges and other bodies which deal or operate in capital markets - noted that in fifteen years, the number of German citizens who are simultaneously employee shareholders decreased dramatically from 1.6 million in 1999 to 800000 in 2014. This is one of the latest arguments demanding measures for a wider implementation of employee ownership. In this case, Kuhn exhorts German governmental authorities to take specific actions to overcome barriers and exploit the full potential of those broader-based plans. 


\subsection{Hypothesis development and variable description}

My model is set by including country-specific factors, derived at by the literature review that might explain the EU level of usage of employee ownership plans, whatever their form. For instance, Mathieu $(2015$, p. 9) reports the major forms of employee ownership plans in Europe as a percentage of total employees (Table 1):

My search for country specific determinants is rather inductive, since cross-national studies are currently scarce (compared to the study typology which I refer to in the previous subchapter); furthermore, there are no longitudinal studies establishing a direct relationship between employee ownership and a nation's or region's cultural, political, legal, economic and social contributing factors.

The study by Festing et al. (1999) is one of the few that tries to recognise these determinants. Despite the authors' recognition of the methodological limitations of the model, they conclude that the determinants of employee ownership incidence are placed in a cultural, legal and institutional perspective. At the same time, those contextual environmental factors influence and are influenced by company-specific factors that operate on the domestic markets. Following the latest developments in global markets and the collapse of the socialist economies of Eastern Europe, it is not possible to understand institutional developments (their origin, influence on performance and adaptation to the operational environment) without understanding the political forces which have caused them (Djankov et al., 2003). Furthermore, Djankov et al. (2003) emphasise that this is precisely there where the most critical institutional differences between countries are set, that is, the type of governance determines the order factors, including the greater or lesser degree of intervention in market regulation in the judicial branch (which could damage the rule of law) and the greater or lesser extent of resources and property concentration.

Another concern is whether the predominant free-market policies in Western economies can encompass the Kelsonian concept of 'economic democracy' described above. Kelso and Adler (1958) advocated an evolution towards a combination of free-market principles with the democratisation of economic power and capital ownership.

However, there is no clear-cut evidence of a setting in which employee ownership arrangements can flourish.

The above-described 'nationality effect' is predicted to play a major role in the dissemination of employee ownership plans throughout the European Union member states, explained by legislative differences (Pendleton et al., 2001) and by the degree of support measures set by governments' macroeconomic policy (Poutsma et al., 2003). Furthermore, several European Union institutions encourage Member States to introduce policy and legislative mechanisms for the dissemination of employee ownership instruments, chiefly through tax incentives (European Commission, 1996, 2002; Lowitzsch and Hashi, 2014).

Accordingly, for an economic background perspective, I use the 'Index of Economic Freedom' (IEF) produced by the Center for Trade and Economics of the Heritage Foundation. The index comprises ten features within the four following dimensions: (1) rule of law (property rights and freedom from corruption), (2) the intrusiveness and size of government (fiscal freedom and government spending), (3) regulatory efficiency (business, labour and monetary freedom) and (4) the openness of markets (trade, investment and financial freedom). In 2015 report, the IEF promoters continue to show a very strong correlation between countries in the highest-ranking positions and some dimensions of human development, namely lower poverty intensity; higher income per capita; higher levels of life expectancy, literacy, education and the standard of living; and higher per capita economic growth, which results in entrepreneurship growth, job creation and innovation (Miller and Kim, 2015).

Table 1: Summary of EFES report statistics, 2008-2012

\begin{tabular}{|l|c|c|c|c|c|}
\hline & 2012 & 2011 & 2010 & 2009 & 2008 \\
\hline Employee owners (thousand people) & 8967 & 9119 & 8876 & 8538 & 8276 \\
\hline Employees' share in the ownership structure & $2.8 \%$ & $2.9 \%$ & $2.9 \%$ & $2.9 \%$ & $2.8 \%$ \\
\hline Capitalisation held by employees (billion $€$ ) & 200 & 237 & 198 & 164 & 239 \\
\hline Percentage of European companies with: & $91.2 \%$ & $90.3 \%$ & $89.4 \%$ & $88.9 \%$ & $84.1 \%$ \\
\hline$-\quad$ Employee ownership & $50.9 \%$ & $50.0 \%$ & $49.1 \%$ & $48.4 \%$ & $47.0 \%$ \\
\hline$-\quad$ Broad-based plans & $62.0 \%$ & $61.2 \%$ & $60.4 \%$ & $59.8 \%$ & $58.4 \%$ \\
\hline
\end{tabular}

Source: Author's construction based on Mathieu (2015, p. 9).

Observations: The above figures encompass, for each year, 31 European countries - the EU-28 plus Iceland, Norway and Switzerland; listed companies and non-listed companies are pooled. 
In sum, I propose to test whether the degree of state intervention in an economy is related to the incidence level of employee ownership, as measured by the IEF. The positivity of the relationship hypothesised below is uncertain.

Hypothesis 1: There is a positive relationship between economic freedom and the incidence level of employee ownership in the EU-20.

The link between labour market regulations and the diffusion of employee ownership plans is an understudied field of research in the European Union context. So far, the vast majority of studies have explored US labour market particularities. However, the latter is structurally different from the EU - such as in the legal mechanisms for workers' protection and, as a result, in the degree of flexibility of the workforce. Moreover, labour markets are affected by the government's role in the use of the core functions of national welfare policies (Blekesaune and Quadagno, 2003).

In order to compete in the large global market and to cope with the demand for greater flexibility, companies have had to assume high levels of cooperation and participation between managers or executives and workers' teams (Poutsma and Huijgen, 1999). By comparing employee participation forms amongst EU and US firms, Gill and Krieger (2000) suggest that the European model of participation is somewhat less flexible and competitive, generating high unemployment rates. In addition, the authors highlight that the EU model of participation has a greater degree of job protection - with the strong influence of labour protection measures from the welfare state. Furthermore, those outcomes are strongly influenced by trade unions, where collective bargaining and tripartite regulation prevail. Bryson et al. (2013) find that the extent of labour market regulation is negatively correlated with the dissemination of incentive pay schemes (which include employee ownership plans).

To account for labour markets' regulatory practices, I elect the 'labour market regulation' index published by the Fraser Institute. In the 2015 report of The Economic Freedom of the World, Gwartney et al. (2015) state that labour market overregulation reduces the power of employees and employers to negotiate their contracts freely, thus reducing economic freedom. This aggregate indicator includes measures of (1) hiring regulations and minimum wage, (2) hiring and firing regulations, (3) centralised collective bargaining, (4) regulation of working hours, (5) mandated cost of worker dismissal and (6) the use of conscription. A free labour market will rank highly in this indicator.
Hypothesis 2: There is a positive relationship between labour market freedom and the incidence level of employee ownership in the EU-20.

Another branch of unexplored research on widespread employee ownership is its relationship with financial literacy. There is a bulk of economic empirical research linking economic growth with citizens' financial knowledge. Lusardi and Mitchell (2014) note that since welfare after retirement regulations have been loosened from centralised governmental intermediation through social security or employers' defined contribution plans, retirees have to make crucial financial decisions. An apparently simple dichotomous financial decision like saving versus consuming does not fit in a world where financial products are increasing in number, sophistication and complexity. In circumstances where individuals have to face the risk to avoid losing his/her entire life savings, an individual needs to reason about the opportunity cost of his/her decision.

This shift from defined benefit pensions to defined contribution schemes stresses the importance of financial knowledge to avoid asset decumulation (Lusardi and Mitchell, 2014, p. 6) - that is, lessening value. This reasoning can easily be extended to other voluntary, broad-based, asset accumulating defined contributions plans such as employee stock ownership plans (ESOPs). Christelis et al. (2010) observe that individuals' cognitive abilities, such as numeracy, verbal fluency and memory, are positively related with stock market participation by citizens. Rosen et al. (2005) note that financial literacy is crucial for participatory democracy at the workplace through ownership, enabling workers to act like owners by understanding the major variables that affect their businesses. Pendleton (2010) highlights the need for employee education on risk and investment implications, and for awareness about employee ownership plans' financial features. For Kaarsemaker and Poutsma (2006), financial literacy is beneficial for employee ownership success.

Following the Global Competitiveness Index (GCI) of the World Economic Forum (WEF) (Schwab, 2014), there are the following proxies for financial literacy: (1) quantity of education, which is an aggregate measure of (a) secondary education enrolment rate and (b) tertiary education enrolment rate (both based on hard data); and (2) quality of education, which aggregates four indicators - (a) the quality of the education system, (b) the quality of math and science education, (c) the quality of management schools and (d) internet access in schools (all based on survey data; e.g. the 2014 report was based on the opinion of 14,000 business leaders worldwide - Executive Opinion Survey). ${ }^{6}$

Following Christelis et al.'s (2010) findings related to cognitive abilities, it seems reasonable to select the second indicator according to the qualitative nature of education.

\footnotetext{
${ }^{6}$ The complete dataset is available on a dedicated WEF website: http://www.weforum.org/reports/.
} 
Hypothesis 3: There is a positive relationship between financial literacy and the incidence level of employee ownership in the EU-20.

The development of financial markets plays a major role in widespread employee ownership. As discussed earlier in this chapter, the dynamics of such development result in the widespread participation of small investors and/ or families. Cross-countries studies have proved that this is a determinant concerning the level and extent of usage of employee financial participation schemes, mainly of stock ownership plans (Bryson et al., 2013; McCartney, 2004; Poutsma and Nijs, 2003).

Through the above-mentioned GCI (Schwab, 2014), I draw two proxies for financial market development, as follows: (1) (financial market) efficiency, which is an aggregate measure of (a) the availability of financial services, (b) the affordability of financial services, (c) financing (level) through the local equity market, (d) ease of access to loans and (e) venture capital availability (all based on the WEF Executive Opinion Survey); and (2) trustworthiness and confidence, which integrates (a) the soundness of banks, (b) the regulation of securities exchanges (both based on survey data) and (c) the legal rights index (secondary source, based on the index computed by the Wold Bank by its subsidiary the International Finance Corporation).

Analysing both indicators, which are strongly correlated at 0.802 , and to avoid collinearity, I drop the first, since the second is seemingly more concerned with a rationale for citizens to opt for stock plans.

Hypothesis 4: There is a positive relationship between financial market development and the incidence level of employee ownership in the EU-20.

\subsection{Sample selection and analytical methods}

An employee ownership researcher will inevitably encounter a lack of data to carry out his/her research project. At the European level, there are some data references usually included in the European Company Surveys (ECS) or in the European Working Conditions Surveys (ECWS), both carried out by the European Foundation for the Improvement of Living and Working Conditions (Eurofound), with the ECS performed every four years (since 2004) and the ECWS every five years (since 2005). Therefore, longitudinal data studies testing the incidence level were initially almost impossible to perform, since researchers could only rely on postal surveys Eurofound had designed. However, in 2006, the European Federation of Employee Share Ownership (EFES) first published the Annual Economic
Survey of Employee Ownership in European Countries, comprising 2006/2007 data. This year, the EFES publishes the seventh consecutive report, which contains 2014 data - a major breakthrough for the ownership research community committed to evaluating European financial participation issues and their developments.

The EFES annual reports include European countries' aggregated data on all large European listed companies (which I label as the 'thorough sample subset' due to its representativeness) and a vast majority of the biggest European non-listed employee-owned companies, chiefly constituted by workers' cooperatives (where the representativeness is disputable). For the 2014 EFES report, Mathieu (2015) compiled information about 2509 European companies, ${ }^{7} 2225$ of which represent the European listed companies whose market capitalisation is 200 million euros or more. Although they make up just one-quarter of all European listed companies, they are responsible for $98 \%$ of the total market capitalisation and for $94 \%$ of the employment within this realm (Mathieu, 2015, p. 10).

In terms of stock trade companies in the 28 European Union member states (EU-28), the EFES database poses many challenges to researchers in that it raises the market capitalisation bar to the amount referred. The depiction of countries' employee owners in the sample depends on how developed stock markets are; this is measured through their liquidity, the number of listed firms and their market capitalisation related to countries' internal productivity measures (e.g. the gross domestic product [GDP]), among other indicators. Moreover, companies' ownership structure - whether it is more or less concentrated and held by institutional investors or predominantly by small investors - plays a big part in capital markets' development. A higher number of listed companies with a large majority of small investors enables the use of stock ownership plans. This explains, for instance, the great expansion of these plans in the UK (Poutsma and Nijs, 2003, p. 889) even before the Nuttall Review (Nuttall, 2012), which supported the British government's agenda to boost employee ownership.

Due to the thoroughness of the above-mentioned list (through the EFES methodological capitalisation floor threshold) and the unclear representativeness of report's second subset (non-listed employee-owned companies), my dependent variable, which I label 'Employee Ownership', consists of 'employee owners as a percentage of all employees in listed companies' (; equation 1). Thus, the dependent variable is my own construction based on published data by the EFES, because Mathieu (2015) does not report it directly. Nevertheless, my formulation can be confused with the described 'democratisation rate of employee ownership' (calculated by dividing the total number of employee owners by the total number of employees). Actually, for listed companies, there is only the indicator

\footnotetext{
${ }^{7}$ The report comprises data from 31 European countries - the 28 European Union member states plus Switzerland, Norway and Iceland.
} 
'Employee owners in \% of all employees in listed companies having employee share plans', which excludes the number of employees of listed companies with no employee shareholders from the ratio (see, for instance, Mathieu, 2015, p. 137, column 204 for 2012 results).

$e o_{i t}=\frac{t e_{i t}-\text { teo }_{i t}}{\text { tenl }_{i t}-\text { teonl }_{i t}}$

where te ${ }_{i t}$ is the total number of employees, stands for the total number of employee owners, tenl $\mathrm{it}_{\mathrm{t}}$ represents the total number of employees in non-listed companies and teonl ${ }_{i t}$ is the total number of employee owners in non-listed companies for country $i$ and year $t$. The time variable $t$ spans all years from 2008 and 2012, notwithstanding the availability of 2013 and 2014 data for the dependent variable, as well as for the vast majority of the proposed explanatory variables. This is because 'market capitalisation of listed companies (\% of GDP)' from World Bank's (WB's) World Development Indicators (WDI) ends at 2012. ${ }^{8}$ Furthermore, to fully integrate the EU's 2007 enlargement, I limit the time series start point to 2008 .

As explained above, despite the major improvement brought about by the publication of EFES reports and database construction, some shortcomings must be offset. Based on the 2014 EFES report (Mathieu, 2015), the country choice criteria for sample inclusion followed certain research conditions, as follows:

Condition 1: Available data for computing Equation 1 any country with missing data is rejected;

Condition 2: Market capitalisation (of listed companies) to GDP: at least two years above the first quar- tile for the respective year; otherwise, the country is excluded (WDI statistics);

Condition 3: Number of listed companies included in the 2014 EFES report above the first quartile for 2008-2012 or the number of listed companies below the first quartile for the global average of 2008-2012 (WDI statistics, except for Spain, due to the unreliable figure computed - reported, for instance, by Machado (2011) - where data were collected from the CNMV, the Spanish securities market commission; Comisión Nacional de Mercado de Valores, 2008, 2010, 2012).

Following these criteria, I excluded the following countries from the analysis: (1) Bulgaria, Cyprus, Estonia, Latvia, Romania, and Slovak Republic, which violate the latter two conditions; (2) Lithuania, which infringes on the second condition; and (3) Croatia, which violates the third condition.

Overall, regarding the 25 th percentile in Table 2 , my calculations constructed a panel dataset which includes observations for five years from twenty EU member states, with a hundred computed observations (henceforth referred to as 'EU-20').

Table 3 summarises all of the independent variables which will explain the employee ownership incidence in country $i$ at the year $t$ - the author-constructed .

Analysing Table 4, there are no strong correlations between the variables. Thus, the possibility of multicollinearity is remote, since there are no highly correlated predictor variables to include in the regression model. ${ }^{9}$

Table 2: Summary statistics for panel ID (country) variable selection

\begin{tabular}{|c|c|c|c|c|c|c|c|c|}
\hline Measures & 2008 & 2009 & 2010 & 2011 & 2012 & $\begin{array}{c}\text { Listed } \\
(\text { EFES })\end{array}$ & $\begin{array}{c}\text { Listed } \\
(\text { WB })\end{array}$ & $\begin{array}{c}\text { EFES/WB } \\
(\%)\end{array}$ \\
\hline Mean & 31.53 & 43.29 & 45.92 & 35.89 & 41.67 & 70.6 & 306.4 & 31.05 \\
\hline Maximum & 120.91 & 210.52 & 193.94 & 114.70 & 124.95 & 490 & 2200 & 72.71 \\
\hline $75^{\text {th }}$ percentile & 41.73 & 57.28 & 68.25 & 52.50 & 66.41 & 89 & 324 & 45.21 \\
\hline Median & 25.86 & 25.93 & 29.46 & 25.78 & 32.94 & 32 & 123 & 29.16 \\
\hline $\mathbf{2 5}^{\text {th }}$ percentile & $\mathbf{1 6 . 6 9}$ & $\mathbf{1 5 . 0 3}$ & $\mathbf{1 7 . 9 4}$ & $\mathbf{1 1 . 8 2}$ & $\mathbf{1 3 . 0 1}$ & $\mathbf{8}$ & $\mathbf{4 7}$ & $\mathbf{1 7 . 1 2}$ \\
\hline Minimum & 4.78 & 5.27 & 4.66 & 3.78 & 3.93 & 3 & 16 & 0.78 \\
\hline
\end{tabular}

Source: Author's calculation based on World Bank, WDI, available at http://databank.worldbank.org/data/reports.aspx?source=world-development-indicators, for 27 countries, and on CNMV (2008, 2010, 2012) for Spain.

Observations: 2008 to 2012 refers to average market capitalisation (of listed companies) to the GDP for those years; Listed (EFES) refers to number of listed companies included in the 2014 EFES report (see Mathieu, 2015); Listed (WB) refers to the average for 2008 to 2012 number of listed companies reported in World Bank's WDI; EFES/WB (\%) refers to the percentage of EFES listed companies in relation to WB listed companies.

\footnotetext{
${ }^{8}$ On a final commentary including cross-sectional time metadata, the World Bank WDI team states that the 'series stock market data were last updated April 2013. Standard \& Poor's has discontinued the "Global Stock Markets Factbook" and database.

${ }^{9}$ I address the multicollinearity problem below by running the variance inflation indicators and tolerance levels for the independent variables; this confirms the presence of low multicollinearity effects.
} 
Table 3: Independent (and control) variables description

\begin{tabular}{|c|c|c|c|c|}
\hline Variable name & Description & Measure & Source & $\begin{array}{l}\text { Expected } \\
\text { effect }\end{array}$ \\
\hline $\begin{array}{l}\text { Index of economic } \\
\text { freedom } \\
\text { (ief) }\end{array}$ & $\begin{array}{l}\text { (Measures the extent of) absolute right of property } \\
\text { ownership; full freedom of movement for labour, cap- } \\
\text { ital, and goods; and an absolute absence of coercion or } \\
\text { constraint of economic activity beyond that which is } \\
\text { necessary for the protection and maintenance of liberty } \\
\text { itself }\end{array}$ & $\begin{array}{l}0 \text { to } 100, \text { higher } \\
\text { values relate to } \\
\text { a better index }\end{array}$ & $\begin{array}{l}\text { Heritage } \\
\text { Found. }\end{array}$ & + \\
\hline $\begin{array}{l}\text { Labour market free- } \\
\text { dom } \\
\text { (labourmkt) }\end{array}$ & $\begin{array}{l}\text { (Measures the extent of) labour markets' regulations } \\
\text { restraining employee-employer relations in determin- } \\
\text { ing wages, hiring/firing and the use of conscription }\end{array}$ & $\begin{array}{l}0 \text { to } 10 \text {, higher } \\
\text { rates relate to } \\
\text { better labour } \\
\text { market freedom }\end{array}$ & $\begin{array}{l}\text { The Fraser } \\
\text { Institute }\end{array}$ & + \\
\hline $\begin{array}{l}\text { Quality of education } \\
\text { (qualedu) }\end{array}$ & Quality of education as evaluated by business leaders & $\begin{array}{l}\text { 1-7, from poor } \\
\text { to excellent }\end{array}$ & WEF & + \\
\hline $\begin{array}{l}\text { Financial markets } \\
\text { trustworthiness and } \\
\text { confidence } \\
\text { (fmtrust) }\end{array}$ & $\begin{array}{l}\text { Sophistication of financial markets which can make } \\
\text { capital available for private-sector investment from } \\
\text { such sources as loans from a sound banking sector, } \\
\text { well-regulated securities exchanges, venture capital } \\
\text { and other financial products }\end{array}$ & $\begin{array}{l}1-7, \text { from poor } \\
\text { to excellent }\end{array}$ & WEF & + \\
\hline
\end{tabular}

Table 4: Correlation matrix

\begin{tabular}{|c|c|c|c|c|c|}
\hline & 1 & 2 & 3 & 4 & 5 \\
\hline 1. EO & 1.000 & & & & \\
\hline 2. IEF & 0.010 & 1.000 & & & \\
\hline 3. LABOURMKT & 0.016 & 0.386 & 1.000 & & \\
\hline 4. QUALEDU & 0.439 & 0.610 & 0.284 & 1.000 & \\
\hline 5. FMTRUST & 0.371 & 0.543 & 0.146 & 0.581 & 1.000 \\
\hline
\end{tabular}

The regression equation to test the effect of the variables 2 to 5 (see Table 3 ) on the incidence level of employee ownership in the EU-20, by the classical linear regression model, is as follows:

$e o_{i t}=\beta_{0}+\beta_{1} \cdot$ ief $_{i t}+\beta_{2}$. labourmkt tit $+\beta_{3}$. qualed $_{i t}+\beta_{4} \cdot$ fmtrust $_{i t}+$ $\mu_{i t}$.

However, I assume that there are no behavioural similarities between countries. ${ }^{10}$ Accordingly, the incidence level of employee ownership is affected by unobserved heterogeneity amongst the EU-20 Member States. In that case, a fixed-effect model is the most consistent solution.

In order to control for fixed effects, I regress:

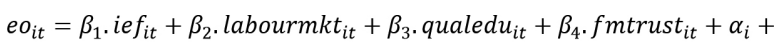

$\mu_{i t}$.

${ }^{10}$ These expected effects for all the EU Member States were reported after a thorough examination of all PEPPER reports results, which I have been conducting over the last fifteen years of research on employee ownership issues; see, for instance, Machado (2013) and the related (and most recent) studies of Hashi and Hashani (2013) and Lowitzsch and Hashi (2014).
Where represents the unknown intercept for each country.

In order to report country intercepts, I introduce the control dummy variables for the countries (panel variables):

$e o_{i t}=\beta_{0}+\beta_{1} \cdot$ eef $_{i t}+(\ldots)+\beta_{4} \cdot$ fmtrust $_{i t}+\delta_{1} \cdot b e_{t}+\delta_{2} \cdot c z_{t}+(\ldots)+$ $\beta \delta_{3} . u k_{t}+\mu_{i t}$.

There are 19 country dummies, since the Austria country dummy was dropped (and is used as the reference country) to avoid perfect multicollinearity. Here, stand for Belgium, the Czech Republic and the United Kingdom dummies, respectively. 


\section{Empirical results}

With the aim of testing the stated hypothesis that independent variables (see Table 3) relate to the incidence level of employee ownership, I perform a linear regression (equations 2 to 4 ).

For the first regression, despite the goodness of fit demonstrated by the F test, when I perform the F test of the joint significance of the fixed effects intercepts, the null hypothesis is not rejected $\left(\mathrm{H}_{0}\right.$ : All of intercepts of each group's fixed effect are zero, i.e. heterogeneity of each group is observed). If the null hypothesis is rejected, then the pooled OLS model must be rejected. ${ }^{11}$

The random effects model, including the dummy variables for the countries, produces the same results as the least squares dummy variable (LSDV). Performing the Breusch and Pagan Lagrangian multiplier test for random effects, the random effects model is not rejected. Again, according to my model specifications, I conclude that the pooled OLS model does not represent the best estimates to predict the incidence level of employee ownership in the EU-20.

Finally, I test whether the unique root of errors (represented above by ) is uncorrelated with the independent variables by using the Hausman Test. The test returns a chi-square of 559.92 with a p-value less than .000 , therefore clearly rejecting the hypothesis of random effects.

In accordance with the previous tests, I perform the following regressions:

The first model (equation 3) controls for fixed effects but produces an incorrect $\mathrm{F}$ score for the model test, as with the adjusted $\mathrm{R}^{2}$. Nevertheless, that could be determined by regressing Model 2 (equation 4).

The second model (equation 4), controlling for the country, would necessarily produce the same estimates. This model also facilitates the interpretation of the effects on independent variables despite the heterogeneity of the 'countries' (fixed effects). The estimates produced for the dummies are statistically significant, even for high p-values, except for Austria, Germany, Greece and the United Kingdom, with the Finland and Poland dummies intercepts statistically significant for an alpha of .1 (see Appendix 1 for all country dummies).

Observing the correlations of the estimated coefficients, there are no high correlations between pairs of coefficients, thus indicating that there is no tendency to discover collinearity. In addition, using Ender's Collinearity Diagnostics $^{12}$ tools for STATA, this tendency is not identifiable. Computing the variance inflation factors (VIFs), knowing that a high VIF is normally above 10.0 (see, for

Table 5: Model regressions: equations 3 and 4 - fixed effects models

\begin{tabular}{|c|c|c|}
\hline Variables & Model 1 & Model 2 \\
\hline \multirow{2}{*}{ ief } & $0.483806^{*}$ & $0.483806^{*}$ \\
\hline & $(0.203503)$ & $(0.184639)$ \\
\hline \multirow{2}{*}{ labourmkt } & 1.022869 & 1.022869 \\
\hline & $(0.711437)$ & $(1.238206)$ \\
\hline \multirow{2}{*}{ qualedu } & -0.5718 & -0.5718 \\
\hline & $(1.767228)$ & $(1.482906)$ \\
\hline \multirow{2}{*}{ fmtrust } & 0.5947682 & 0.594768 \\
\hline & $(0.708666)$ & $(0.872341)$ \\
\hline \multirow{2}{*}{ intercept } & -23.4974 & -19.3234 \\
\hline & $(14.93833)$ & (17.95385) \\
\hline F test & & $\mathrm{F}(23,76)=130.57^{* * *}$ \\
\hline $\mathrm{R}^{2}$ & & 0.9753 \\
\hline Adj. $R^{2}$ & & 0.9678 \\
\hline $\mathrm{N}$ & 100 & 100 \\
\hline
\end{tabular}

Observations: ${ }^{*} \mathrm{p}<.05 ;{ }^{* *} \mathrm{p}<.01 ; * * * \mathrm{p}<.001$ (standard errors for equation 3 and robust standard errors for equation 4 are in parentheses); dependent variable: eo; intercept in equation 4 refers to Austria [see Annex 1 for country dummy intercepts]

${ }^{11}$ Running the fixed effects model or performing the Wald test ( $F$ test) for the dummy variables after running the LSDV regression accounts for the heterogeneity within groups.

${ }^{12}$ Collinearity Diagnostics tools developed for Stata by Philip B. Ender. 
instance, Hair et al., 2009; Kennedy, 2003; Kutner et al., 2004), or its reciprocal - the tolerance level - is below 0.1 , none of the variables of the fixed-effect regression presents values over and under those thresholds, with an overall mean VIF of 1.36. Therefore, I can assert that the correlation between the independent variables does not produce unreliable estimates of regression coefficients.

According to the results produced by the fixed-effect models above (see Table 5), with the overall goodness of fit measures performing very well (both the adjusted $\mathrm{R}^{2}$ and $\mathrm{F}$ test), there is compelling evidence that the extent of economic freedom, as measured by the Index of Economic Freedom, relates positively with employee ownership prevalence, which is statistically significant for an alpha of .05 in the LSDV model. That is, for a 1-point increase in this variable, employee ownership is expected to increase by .48 percentage points, which supports Hypothesis 1 (robust estimation, actual p-value of .011). This result encompasses the setting formulated by Kelso and Adler (1958, 1961) and Kelso and Kelso (1991).

However, statistically significant relations were not found between the employee ownership usage and the labour market freedom or the financial markets trustworthiness variables. Despite the stated positive effects, the data yield high p-values and robust standard errors for both variables, meaning that the stated hypotheses 2 and 4 cannot be accepted or rejected.

Furthermore, quality of education is statistically insignificant, rendering even larger $\mathrm{p}$-values and robust standard errors, revealing an unexpected signal. Thus, Hypothesis 3 failed to be confirmed.

\section{Discussion and conclusions}

According to my research hypotheses, there is a linkage between economic democracy, measured through the employee ownership level of usage, and economic freedom. That result can underline Kelso and Adler's (1958, 1961), and Kelso and Kelso's (1991) reasoning that a free-market economy is needed as framework to develop employee ownership arrangements.

In order to overcome limitations of the current study it is necessary to carry out cross-country- (or cross-region)based studies, deepening our understanding about the factors that promote the implementation of employee ownership in the EU. We need also more profound knowledge about the factors that impede the employee ownership harmonisation at the EU level. ${ }^{13}$ To this end, corporate governance mechanisms, practices, and cross-cultural controls should be taken into account to better understand in more detail how businesses run employee ownership arrangements as Festing et al. (1999) have shown.
Following Lowitzsch and Hashi (2014) and several EU bodies recommendations, employee ownership is a powerful political, economic and social instrument that can cope with the excessive (and challenging) capital accumulation in the EU. In fact, employee ownership may actually handle the widening income inequality in the Western world that can also be considered to constitute a threat to the political democracy. As Kelso once stated, referring to the United States of America:

Today we are no longer a democracy. One man, one vote is not democracy; it is only democratic as to political power: we are a political democracy inside an economic plutocracy (Keynote speech at the ESOP Association 1984 meeting; ESOP Association, 1984).

This warning could be extended to Westernised European nations, largely in relation to the enduring aftermath of the world economic crisis since 2007. However, Kelso's and Adler's panacea for preventing an 'economic plutocracy', namely to reduce income inequality by widespread employee ownership, put forward in their ground-breaking book, The Capitalist Manifesto (Kelso and Adler, 1958), has to be taken with a grain of salt, since the linkage is not definitely set. Their straightforward reasoning seems to be affected recently by baffling empirical evidence. For instance, Buchele et al. (2010, p. 352) suggest that broadbased employee stock ownership plans may be not, by itself, sufficient to lessen income inequality, though they spread income to a wider range of society. Actually, the countries which are so-called 'employee ownership champions' (e.g., the United States) ${ }^{14}$ are deepening their income inequality.

Presumably, economic democracy does not consist of the simple opposing dichotomy of capital hiring labour versus labour hiring capital. Rather it contains a radical change towards a collaborative economy that is difficult to achieve, and where high barriers to change exist. Gradual and steady steps are required. The shift to a more democratic economy consists of broadening capital ownership to those who participate in producing goods and services, sharing the income earned in this way. But at the same time it must be founded on changing the prevailing capital concentration system to a decentralised, cooperative, sharing economic system within a suitable free-market context.

Finally, some limitations of this study have to be mentioned. With regard to the dependent variable construction, this study should be read carefully, mainly because of severe limitations to data availability on employee ownership plans carried out by European Union countries. In fact, the constructed dependent variable ('eo') relies solely on an EFES dataset. As already noted above, the EFES dataset encompasses only one-quarter of listed European companies, so despite its representativeness when accounting for market capitalisation, the dataset does not account for a major part of the EU economy; to be exact, the

\footnotetext{
${ }^{13}$ However, as I state above, in a qualitative perspective, country differences were already encountered by most of the PEPPER reports and the latest thorough study at the level of Europe, that of Lowitzsch and Hashi (2014).

${ }^{14}$ See, for instance, Keeley (2015) for the last update of income inequality around the world.
} 
EFES dataset excludes the small and medium-sized enterprises (SMEs). ${ }^{15}$ Moreover, as Richter and Schrader (2013) point out, the incidence of employee ownership practices may be larger when SMEs are taken into account, and one should reckon with different employee ownership arrangements in SMEs than in larger companies.

\section{Acknowledgements}

This paper was presented at the 9th International Conference in Critical Management Studies (CMS), held by the University of Leicester, 8-10 July 2015. The research was financially supported by Porto Polytechnic's R\&D units support programme, specifically the grant conveyed for the Applied Management Research Unit (UNIAG.IPP) researchers. I would like to thank Olaf Kranz and Thomas Steger, as convenors of the CMS stream on employee ownership, for their guidance, suggestions and insights for this research paper. I also want to thank Maciej Kozlowski and Pawel Ruszkowski, both as paper discussants, for their insightful remarks and cooperation. All errors and responsibilities are mine.

\section{References}

Ashford, R. (1994). The Binary Economics of Louis Kelso: A Democratic Private Property System for Growth and Justice. In J. H. Miller (Ed.), Curing World Poverty: The New Role of Property (pp. 351-375). Saint Louis. MO: Social Justice Review and The Center for Economic and Social Justice.

Ashford, R. (2011). Broadening the right to acquire capital with the earnings of capital: The missing link to sustainable economic recovery and growth, http://dx.doi. org/10.2139/ssrn.1342183

Black, S. E., \& Lynch, L. M. (2001). How to compete: The impact of workplace practices and information technology on productivity. Review of Economics and Statistics, 83(3), 434-445, http://dx.doi. org/10.1162/00346530152480081

Blasi, J. R., Freeman, R. B., \& Kruse, D. L. (20, 14). The citizen's share: Reducing inequality in the 21st century. New Haven, CT: Yale University Press.

Blekesaune, M., \& Quadagno, J. (2003). Public Attitudes toward Welfare State Policies: A Comparative Analysis of 24 Nations. European Sociological Review, 19(5), 415-427, http://dx.doi.org/10.1093/esr/19.5.415

Bryson, A., Freeman, R. B., Lucifora, C., Pellizzari, M., \& Perotin, V. (2013). Paying for performance: incentive pay schemes and employees' financial participation. In: T. Boeri, C. Lucifora, \& K. J. Murphy (Eds.), Executive Remuneration and Employee Performance-Related Pay: A Transatlantic Perspective (pp. 123-278).
Oxford, UK: Oxford University Press.

Buchele, R., Kruse, D. L., Rodgers, L., \& Scharf, A. (2010). Show me the money: Does shared capitalism share the wealth? In D. L. Kruse, R. B. Freeman, \& J. R. Blasi (Eds.), Shared capitalism at work: Employee ownership, profit and gain sharing, and broad-based stock options (pp. 351-375). Chicago: University of Chicago Press.

Christelis, D., Jappelli, T., \& Padula, M. (2010). Cognitive abilities and portfolio choice. European Economic Review, 54(1), 18-38, http://dx.doi.org/10.1016/j.euroecorev.2009.04.001

Comisión Nacional de Mercado de Valores. (2008). CNMV annual report regarding its actions and the securities markets. Madrid: CNMV.

Comisión Nacional de Mercado de Valores. (2010). CNMV annual report regarding its actions and the securities markets. Madrid: CNMV.

Comisión Nacional de Mercado de Valores. (2012). CNMV annual report regarding its actions and the securities markets. Madrid: CNMV.

Djankov, S., La Porta, R., Lopez-de-Silanes, F., \& Shleifer, A. (2003). Appropriate institutions. In B. Pleskovic \& N. Stern (Eds.), Annual World Bank Conference on Development Economics 2003: The new reform agenda (pp. 283-298). New York: The World Bank and Oxford University Press.

Employee Stock Ownership Plan Association (1984). Luncheon address by Louis O. Kelso, ESOP Association meeting. Washington, DC. Retrieved from http://kelsoinstitute.org/louiskelso/kelso-paradigm/who-whatand-why/

European Commission. (1996). PEPPER II. Promotion of participation by employed persons in profits and enterprise results (including equity participation) in Member States 1996. Report from the Commission. COM (96) 697 final, 8 January 1997.

European Commission. (2002). Communication from the Commission to the Council, the European Parliament, the Economic and Social Committee and the Committee of the Regions: On a framework for the promotion of employee financial participation. COM (2002) 364 final.

European Commission. (2015). Annual Report on European SMEs 2014/2015: SMEs start hiring again. SME Performance Review 2014/2015. European Commission, Directorate-General for Internal Market, Industry, Entrepreneurship and SMEs, http://dx.doi. org/10.2873/886211

Festing, M., Groening, Y., Kabst, R., \& Weber, W. (1999). Financial participation in Europe-Determinants and outcomes. Economic and Industrial Democracy, 20(2), 295-329, http://dx.doi. org/10.1177/0143831X99202007

\footnotetext{
${ }_{15}$ According to the last available data, in 2014 the SMEs in the EU-28 accounted for $99.8 \%$ of all companies in the non-financial business sector, employing about 90 million people (which covered $67 \%$ of total employment) and representing $58 \%$ of the value added generated in that sector (European Commission, 2015).
} 
Freeman, R. B. (2014). Who owns the robots rules the world. IZA World of Labor, 4, http://dx.doi. org/10.15185/izawol.5

Gill, C., \& Krieger, H. (2000). Recent Survey Evidence on Participation in Europe: Towards a European Model? European Journal of Industrial Relations, 6(1), 109132. , http://dx.doi.org/10.1177/095968010061006

Gwartney, J., Lawson, R., \& Hall, J. (2015). Economic Freedom of the World: 2015 Annual Report. Vancouver: Fraser Institute.

Hair, J. F., Black, W. C., Babin, B. J., \& Anderson, R. E. (2009). Multivariate Data Analysis (7th ed.). Upper Saddle River, NJ: Prentice Hall.

Hashi, I., \& Hashani, A. (2013). Determinants of financial participation in the EU: Employers' and employees' perspectives. In D. L. Kruse (Ed.), Sharing ownership, profits, and decision-making in the 21st century: Vol. 14. Advances in the economic analysis of participatory \& labor-managed firms (pp. 187-215). Bingley, UK: Emerald.

Ichniowski, C., Shaw, K., \& Prennushi, G. (1997). The effects of human resource management practices on productivity: A study of steel finishing lines. American Economic Review, 87(3), 291-313.

Kaarsemaker, E., Pendleton, A., \& Poutsma, E. (2010). Employee share ownership. In A. Wilkinson, P. J. Gollan, M. Marchington, \& D. Lewin (Eds.), The Oxford Handbook of Participation in Organizations (pp. 315-337). Oxford, UK: Oxford University Press, http://dx.doi.org/10.1093/oxfordhb/9780199207268.003.0013

Kaarsemaker, E., \& Poutsma, E. (2006). The Fit of Employee Ownership with other Human Resource Management Practices: Theoretical and Empirical Suggestions Regarding the Existence of an Ownership High-Performance Work System. Economic and Industrial Democracy, 27(4), pp.669-685, http://dx.doi. org/10.1177/0143831X06069009

Keeley, B. (2015). Income Inequality: The Gap between Rich and Poor (OECD Insights). Paris: OECD Publishing, http://dx.doi.org/10.1787/9789264246010-en .

Kelso, L. O., \& Adler, M. J. (1958). The capitalist manifesto. New York: Random House.

Kelso, L. O., \& Adler, M. J. (1961). The New Capitalists: A Proposal to Free Economic Growth from the Slavery of Savings. New York: Random House.

Kelso, L. O., \& Kelso, P. H. (1991). Democracy and economic power: Extending the ESOP revolution through binary economics. Lanham, MD: University Press of America.

Kennedy, P. (2003). A guide to econometrics (5th ed.). Cambridge, MA: MIT Press.

Kuhn, N. (2015). Time to take action-Finally supporting employee share ownership. Deutsches Aktieninstitut, Gastbeitrag. Frankfurt: Deutsches Aktieninstitut. Retrieved from http:/www.efesonline.org/DE/2015/ Time $\% 20$ to $\% 20$ take $\% 20$ action $\% 20-\% 20$ Finally $\% 20$ supporting\%20employee $\% 20$ share $\% 20$ ownership.pdf
Kurland, N. G. (2001). A new look at prices and money: the Kelsonian binary model for achieving rapid growth without inflation. The Journal of Socio-Economics, 30(6), 495-515, http://dx.doi.org/10.1016/S10535357(01)00121-4

Kutner, M., Nachtsheim, C., Neter, J., \& Li, W. (2004). Applied linear regression models (5th ed.). Boston: McGraw-Hill/Irwin.

La Porta, R., Lopez-de-Silanes, F. \& Shleifer, A. (2008). The Economic Consequences of Legal Origins. Journal of Economic Literature, 46(2), 285-332, http://dx. doi.org/10.1257/jel.46.2.285

Lowitzsch, J., \& Hashi, I. (2014). The promotion of employee ownership and participation. European Commission. Brussels: European Union. Retrieved from http://ec.europa.eu/internal_market/company/docs/ modern/141028-study-for-dg-markt en.pdf

Lusardi, A., \& Mitchell, O. S. (2014). The economic importance of financial literacy: Theory and evidence. Journal of Economic Literature, 52(1), 5-44, http:// dx.doi.org/10.1257/jel.52.1.5

Machado, R. B. (2011). Participación de los trabajadores en el capital de la empresa: su implementación y viabilidad en Portugal. Análisis de 14 países de la Unión Europea. Madrid: Universidad Complutense de Madrid.

Machado, R. B. (2013). La participación de los trabajadores en las empresas en Europa. Su evolución hasta hoy en día. In G. Lejarriaga, S. Martín, \& A. Muñoz (Eds.), 40 años de historia de las Empresas de Participación. La visión desde la Escuela de Estudios Cooperativos (pp. 549-569). Madrid: Editorial Verbum.

Mathieu, M. (2015). Economic survey of employee ownership in European countries 2014. Brussels: European Federation of Employee Share Ownership.

McCartney, J. (2004). Financial participation in the EU: Indicators for benchmarking. Luxembourg: Office for Official Publications of the European Communities.

Miller, T., \& Kim, A. B. (2015). 2015 Index of Economic Freedom: Promoting economic opportunity and prosperity. Washington, DC: The Heritage Foundation and Dow Jones \& Company.

Nuttall, G. (2012). Sharing success: The Nuttall review of employee ownership. London: Department for Business, Innovation \& Skills (BIS).

Pendleton, A. (2010). Employee share ownership and investment concentration: which employee shareholders fail to diversify? Human Resource Management Journal, 20(2), 157-174, http://dx.doi.org/10.1111/j.17488583.2010.00128.x

Pendleton, A., Poutsma, E., van Ommeren, J., \& Brewster, C. (2001). Employee share ownership and profit-sharing in the European Union. Luxembourg: Office for Official Publications of the European Communities.

Pendleton, A., Poutsma, E., van Ommeren, J., \& Brewster, C. (2003). The incidence and determinants of employee share ownership and profit sharing in Europe. In T. Kato \& J. Pliskin (Ed.), The determinants of the inci- 
dence and the effects of participatory organizations: Vol. 7. Analysis of participatory and labor-managed firms (pp. 141-172). Oxford, UK: JAI Press.

Pierce, J. L., Kostova, T., \& Dirks, K. T. (2001). Toward a theory of psychological ownership in organizations. Academy of Management Review, 26(2), 293-310, http://dx.doi.org/10.5465/AMR.2001.4378028

Poutsma, E. (2001). Recent trends in employee financial participation in the European Union. Luxembourg: Office for Official Publications of the European Communities.

Poutsma, E., \& Huijgen, F. (1999). European Diversity in the Use of Participation Schemes. Economic and Industrial Democracy, 20(2), 197-223, http://dx.doi. org/10.1177/0143831X99202003

Poutsma, E., \& Nijs, W. (2003). The global phenomenon of employee financial participation. International Journal of Human Resource Management, 14(6), 855862, http://dx.doi.org/10.1080/0958519032000106128

Poutsma, E., Nijs, W., \& Poole, M. (2003). Broad-based employee financial participation in the European Union. International Journal of Human Resource Management, 14(6), 863-892, http://dx.doi.org/10.10 $\underline{80 / 0958519032000106119}$

Richter, A., \& Schrader, S. (2013). Reported levels of employee share ownership and the performance of listed companies in Europe. Retrieved from http://www. efesonline.org/Database \%20of\%20employee $\% 20$ ownership/Users/Richter_Schrader_Reported $\% 20$ Levels \%20of\%20ESO $\% 20$ and $\% 20$ the $\% 20$ Performance $\% 20$ of\%20Listed $\% 20$ Companies $\% 20$ in $\% 20$ Europe.pdf
Rosen, C., Case, J. \& Staubus, M. (2005). Equity: why employee ownership is good for business. Boston, MA: Harvard Business School Press.

Schwab, K. (Ed.). (2014). The Global Competitiveness Report 2014-2015: Full Data Edition. Geneva: The World Economic Forum.

Terrell, T. D. (2005). Binary economics: Paradigm shift or cluster of errors? The Quarterly Journal of Austrian Economics, 8(1), 30-50, http://dx.doi.org/10.1007/ s12113-005-1015-4

Uvalic, M. (1991). The PEPPER report: Promotion of employee participation in profits and enterprise results. Commission of the European Communities. Luxembourg: Office for Official publications of the European Communities.

Zundel, A. (2000). Kelso's binary economy as social ethics. The Journal of Socio-Economics, 29(6), 495-515, http://dx.doi.org/10.1016/S1053-5357(00)00108-6

Ricardo B. Machado is an assistant professor in finance at the School of Management and Industrial Studies of Porto Polytechnic. He is a research associate at the Applied Management Research Unit (UNIAG) of Porto Polytechnic, Portugal, and at the School of Co-operative Studies of Universidad Complutense de Madrid, Spain. He received his $\mathrm{PhD}$ degree from Universidad Complutense de Madrid, on employee ownership/financial participation in the EU. His main research interests lie on the linkage between financial markets and employee ownership plans, and on co-ops and employee ownership companies' governance, capital structure and access to external finance. 


\section{Appendix}

Estimates produced by the LSDV model.

\begin{tabular}{|c|c|}
\hline Variables & Equation 4 \\
\hline \multirow[t]{2}{*}{ ief } & $0.483806^{*}$ \\
\hline & $(0.184639)$ \\
\hline \multirow[t]{2}{*}{ labourmkt } & 1.022869 \\
\hline & (1.238206) \\
\hline \multirow[t]{2}{*}{ qualedu } & -0.5718 \\
\hline & (1.482906) \\
\hline \multirow[t]{2}{*}{ fmtrust } & 0.594768 \\
\hline & $(0.872341)$ \\
\hline \multirow{2}{*}{ intercept } & -19.3234 \\
\hline & (17.95385) \\
\hline \multirow{2}{*}{ Belgium } & $-7.004494^{* *}$ \\
\hline & (2.190297) \\
\hline \multirow{2}{*}{ Czech Republic } & $-17.78874^{* * *}$ \\
\hline & $(1.848867)$ \\
\hline \multirow{2}{*}{ Denmark } & $-18.68045^{* * *}$ \\
\hline & $(2.442227)$ \\
\hline \multirow{2}{*}{ Finland } & 3.278714 \\
\hline & $(1.828113)$ \\
\hline \multirow{2}{*}{ France } & $28.06364^{* * *}$ \\
\hline & $(2.156251)$ \\
\hline \multirow{2}{*}{ Germany } & -2.068399 \\
\hline & (1.514879) \\
\hline \multirow{2}{*}{ Greece } & -0.6235071 \\
\hline & (4.072184) \\
\hline \multirow{2}{*}{ Hungary } & $-13.08909^{* * *}$ \\
\hline & $(1.646275)$ \\
\hline \multirow{2}{*}{ Ireland } & $-14.23009^{* * *}$ \\
\hline & $(2.710147)$ \\
\hline
\end{tabular}

\begin{tabular}{|l|c|}
\hline Variables (cont.) & Equation 4 (cont.) \\
\hline \multirow{2}{*}{ Italy } & $-8.473278^{* *}$ \\
\cline { 2 - 2 } & $(2.487798)$ \\
\hline \multirow{2}{*}{ Luxembourg } & $-22.6056^{* * *}$ \\
\cline { 2 - 2 } Malta & $(1.379398)$ \\
\hline \multirow{2}{*}{ The Netherlands } & $14.95946^{* * *}$ \\
\cline { 2 - 2 } & $(2.202847)$ \\
\hline \multirow{2}{*}{ Poland } & $-6.841851^{* *}$ \\
\hline \multirow{2}{*}{ Portugal } & $(1.886378)$ \\
\hline \multirow{2}{*}{ Slovenia } & -6.550877 \\
\hline \multirow{2}{*}{ Spain } & $(3.57401)$ \\
\hline \multirow{2}{*}{ Sweden } & $-9.983032^{* * *}$ \\
\hline \multirow{2}{*}{ United Kingdom } & $(2.558195)$ \\
\hline & $-8.255217^{* * *}$ \\
\hline & $(1.880271)$ \\
\hline & $-11.38902^{* * *}$ \\
\cline { 2 - 2 } & $(2.130543)$ \\
\hline & $16.89149^{* * *}$ \\
\hline & $(0.9646026)$ \\
\hline & 0.9091525 \\
\hline & $(2.972564)$ \\
\hline
\end{tabular}

\begin{tabular}{|l|c|}
\hline $\mathrm{F}$ test & $\mathrm{F}(23.76)=130.57^{* * *}$ \\
\hline $\mathrm{R}^{2}$ & 0.9753 \\
\hline Adj. $\mathrm{R}^{2}$ & 0.9678 \\
\hline $\mathrm{N}$ & 100 \\
\hline
\end{tabular}

Observations: * $\mathrm{p}<.05 ; * * \mathrm{p}<.01 ; * * * \mathrm{p}<.001$ (robust standard errors are in parentheses); dependent variable: eo; intercept refers to Austria [omitted dummy variable in the regression; all country coefficients denote deviations from this intercept] 